\title{
E-Marketing Development and Its Application in Textile Sector of Pakistan-A Theoretical Review
}

\author{
Muhammad Abrar' ${ }^{1}$, Xinming Deng², Asif Ali Safeer ${ }^{1}$, Abdul Ghafoor ${ }^{3}$, Sajjad Ahmad Baig1 ${ }^{*}$ \\ ${ }^{1}$ Department of Management Sciences, National Textile University, Faisalabad, Pakistan \\ ${ }^{2}$ College of Economics and Management, Wuhan University, Wuhan, China \\ ${ }^{3}$ Institute of Business Management Sciences, University of Agriculture, Faisalabad, Pakistan \\ Email: "sajjad.baig@hotmail.com
}

Received 26 May 2016; accepted 19 June 2016; published 22 June 2016

Copyright (C) 2016 by authors and Scientific Research Publishing Inc.

This work is licensed under the Creative Commons Attribution International License (CC BY).

http://creativecommons.org/licenses/by/4.0/

(c) (i) Open Access

\section{Abstract}

Textile sector plays very important role in the economy of Pakistan. It contributes in the form of foreign remittances receipts for textile products exports to international markets. At present global environment, the Pakistan textile sector is not fully apply the latest marketing tools to increase exports and market share in the international markets. In this paper, we presented the E-marketing development model which explained the whole process of e-marketing application like environmental scanning, review marketing goals, and with considering all 4 Ps to make effective decisions for the textile organizations. This model comprehensively guides the companies for effective decision making regarding the application of e-marketing in the textile sector of Pakistan. This current work attempts application of e-marketing in the textile sector of Pakistan and how this e-technology can be rewarding to promote the textile business of Pakistan in the local and foreign markets. This paper also guides the managers to implement e-marketing model in the organizations practically for effective decision making.

\section{Keywords}

Business to Business, E-Marketing, Advertising, Exports, Internet, Textiles, Website

\section{Introduction}

E-marketing strategies involve utilizing existing communication and data networks to exchange uninterrupted

\footnotetext{
${ }^{*}$ Corresponding author.
}

How to cite this paper: Abrar, M., Deng, X.M., Safeer, A.A., Ghafoor, A. and Baig, S.A. (2016) E-Marketing Development and Its Application in Textile Sector of Pakistan-A Theoretical Review. Journal of Service Science and Management, 9, $243-254$. http://dx.doi.org/10.4236/issm.2016.93031 
communication between the company and its customers to provide value to customers beyond traditional networks [1] (Sheth, \& Sharma, 2005). Due to fast growth of information access, plenty of companies have already or planned to move from customary services to electronic surroundings [2] (Taherdoost, Sahibuddin, \& Jalaliyoon. 2013a). E-marketing is the procedure of promoting a brand utilizing the digital networks. E-marketing incorporates every of the exercises a business conducts by means of the general web with the point of pulling in new business, holding current business \& adding to its picture character. Gangeshwer [3] suggested that Web research becomes an increasingly essential tool throughout the purchasing process; plenty of marketers are seeing the benefits. E-Marketing is an element of marketing; it is inevitable for marketing to employ innovation to manage its capacity. We have to deal with the marketing dimensions not with the guide of innovation but rather through technological progresses. Innovative Technological advances are twofold edged swords: they make and overwhelm opportunities [4] (Diola, 2008). The utilization of online marketing has expanded in the course of the most recent ten years and organization proprietors who have not yet included online marketing in their procedure are passing up a major opportunity for extraordinary opportunities. The fundamental purpose of starting e-marketing effort is to promote business through internet with using digital information to achieve the marketing objectives. In e-marketing customized approaches used to get the information of specific customer segments. Marketer should differentiate between customers with low communication participation who prefer straightforward simple messages and those with high communication participation who require comprehensive information to a particular product or service. Whether it is simple or comprehensive, information is a basic requirement for customers to make informed decisions before buying any product either on internet or in conventional [5] (Nadine Sonnenberg, Bertha Jacobs, \& Dinele Momberg, 2014).

Pakistan has advantage of being $4^{\text {th }}$ largest cotton producer in the world. There is so much potential to increase the crop yield. Furthermore Pakistan is the $3^{\text {rd }}$ largest yarn producer in the world. Textile process value chain is long like starting from cotton to finished garment [6]. This long textile value chain is very important in every step from cotton ginning to finish garment. The textile is one of the largest manufacturing sectors of the Pakistan, yet its global share is not large enough. Efficient marketing activities must be carried out to increase the share in global markets. However despite growth and benefits of the internet usage, the work has been carried out to explore the importance of internet in world exports and international markets [7] International textiles trade played vital role in the growth and development of country's economy. Mainly the textile industry is a labor intensive industry.

Mayer [8] has characterized that vast creating nations, for example, China, India, Pakistan and Bangladesh have fused with the world economy since mid-1980s. This has inadequately affected the relative point of preference, the center wage nations, especially in Asia and Latin America, have appreciated in labor serious items. In creating nations, material industry is in development stage though then again it is moving from a top stage into a decrease stage in the created nations. In this paper, we tried to find out that how e-marketing model is innovated and apply to the textile sector of Pakistan to reap out the benefits.

\section{Literature Review}

E-marketing is the strategy that the firm uses the modern communication technology techniques to interact with the potential markets into real markets. It is very essential part of the whole marketing strategy, and it is a sort of marketing tactics to comprehend the marketing objectives based on internet. In network marketing, we use internet in every step of products pre-selling, products selling and products after-selling. It runs in all the process of business s, including new customer development and services to existing customers. E-marketing is based on modern marketing theory with using internet technology and its objectives to meet the requirements of the customers, in order to comprehend the developing new marketing objectives and increasing operating profit [9].

E-Marketing trend is increasing in fast pace, it can be seen a growing effect on customer gain and business developments, which result to sustainable business development. This is reason why e-showcasing systems need in utilizing existing and developing correspondence and information system to convey adjusted and ceaseless correspondence between the business and their clients and to create esteem more noteworthy than old and custom advertising [10]. Showcasing in like manner ended up being more association began as things were at first delivered and after that advertised [1]. E-promoting can be thought to be indistinguishable to internet showcasing and digital marketing. E-promoting is every so often considered to have a more broad degree than internet showcasing since it insinuates automated media, for instance, web, email and remote media, also consolidates 
organization of cutting edge customer data and electronic customer relationship administration systems. The marketing groups (advertisers) are attempted to make purchaser comprehension of the merchandise or service amid promoting systems. Generally, marketing is the method of making or directing an association to offer product or service according to individuals need as well as energetic to purchase [11].

E-Marketing is a key component to general marketing. It offers points of interest that can't regularly be accomplished through ordinary business channels. Company methodology must not be made in isolation, it must be a piece of the more extensive business and marketing plans. A large portion of the examination researchers are utilizing the terms: E-Marketing/Internet-promoting/E-trade/E-business in same way or an alternate wording for the same ramifications, which is mistaken on the grounds that they are diverse in application. For instance, e-marketing has a more extensive degree than web promoting, in light of the fact that internet marketing related just to the internet, World Wide Web, messages. While e-marketing incorporates all these devices like: intranets, extranets and cell telephones. Conversely with these, E-trade and E-business have more extensive degree than e-marketing. Electronic business is known as e-trade which includes the purchasing and offering of items or administrations over electronic environment, for example, the web and other PC systems. These distinctions can be delineated in Figure 1 [12].

E-marketing is a phrase that is used if marketing activities are carried out by using the internet and web related information technologies [13]. There are a number of key elements to e-marketing.

These include, but are not limited to:

- Search engine optimization (SEO).

- Website development: brand or corporate brand.

- E-commerce.

- Social media marketing.

- Advertising (General, PPC and Geo Targeting).

- E-mail marketing.

- Mobile Opportunities (Text messaging, Apps and Bluetooth).

- Community development (Blogging, Forums and Co-creation).

Market development is one of the four option development systems in the Ansoff Matrix. A business sector advancement system includes offering you're existing items into new markets. There are assortments of ways that this system can be accomplished. Customers buying choices are exceedingly overstated by the judgment and choices of one's companions, with shared correspondence going about as an exceptionally pertinent and tried and true wellspring of item data. As already condensed by [14], verbal data sharing is a vital part of the showcasing procedure, as shoppers tend to incredibly depend on the exhortation of others when settling on buy choices, particularly when buys are monetarily or mentally dangerous [15] Buyers are inspired to spread data by means of informal interchanges when they are fulfilled or disappointed with an item [16] and very dedicated to

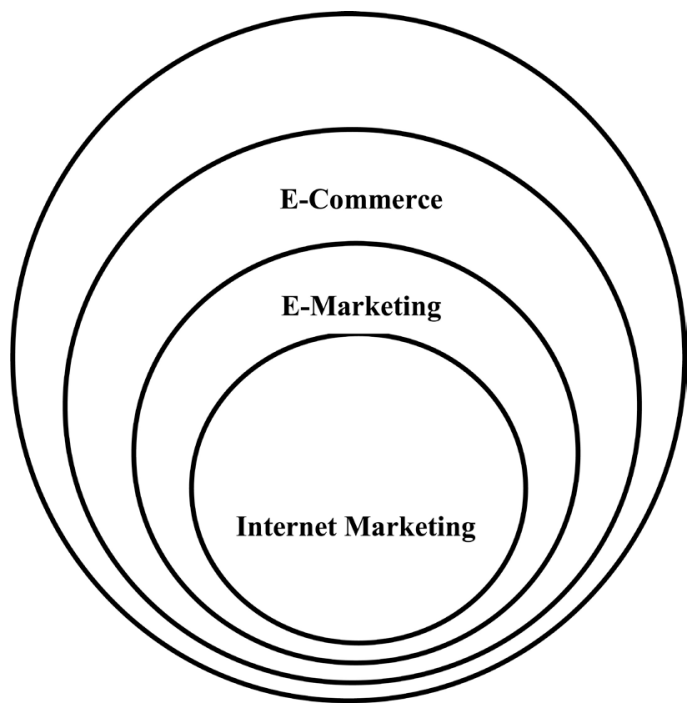

Figure 1. Differences between internet marketing, E-Marketing, E-commerce and E-Business. 
the firm [17]). The approach of the internet has expanded the capacity of people, and potential future clients, to interpersonally interface with each other, consequently making a capable means through which item data can be quickly dispersed and items are more cost-viably embraced by the business sector [18]. As a customary definition marketing comprises of individual and hierarchical exercises that encourage and assist fulfilling trade connections in a dynamic situation through the creation, appropriation, advancement and evaluating of products [19]. This definition is valuable since it highlights distinctive marketing exercises important to accomplish the trade relationship, to be specific item improvement, estimating, advancement and dissemination. The greatest advantage of traditional marketing is re-marketing and brand mindfulness. At the point when an organization delivers another item with a specific end goal to enter to the business sector need to have a considerable measure of advertising endeavors until to continue the client psyche and afterward can move towards new market. Traditional marketing is more commonplace for individuals in view of the durability [11]. Usually, traditional marketing is making just a neighborhood meeting yet it is not bound to one. Along these lines, simply little number of individuals who will watch it might indeed be avid to utilize item and marketing the consequences of electronic advertising is less demanding to assess contrast with traditional marketing; and another focal points is that a computerized operation can accomplish a boundless viewers [11]. Other than that it is conceivable to adjust an advanced operation to accomplish a nearby gathering of people in spite of the fact that it can likewise be pertinent on the web and achieve the entire globe when suitable. Electronic promoting is additionally an exceptionally intelligent method for coming to a group of people since it makes utilization of social outlets [11]. It is clearly stated that e-marketing instruments have been propelled and is turning out to be more modern in those marketing methodologies, so investigating about all the diverse e-marketing channels that can bolster the marketing endeavors which is a decent vital move. What's more, this article will concentrate on virtual market space which rising at the e-marketing fields.

\section{Virtual Market Place}

The new virtual marketing opportunities are shaped by e-commerce. World Wide Web environment is based on information and intangible value. Virtual market-place is the forum to bring together demand and supply as well as technology and economic needs to boost the employment resources as well as the selling process [20]. In order to coordinate numerous business contacts different topic-oriented electronic market places are increasingly emerge, electronic market is considered a trade system initiated for particular business transactions [21] [22]. The main function of the electronic market is facilitating business transactions for customers and sellers-has remained [23]. Virtual market is helpful to minimize transportation costs, customers can navigate the different markets to find goods \& services they want to purchase [24]. Therefore, in a virtual market transaction, the information will be transferred from physical suppliers to customers to conclude the sales deals.

\section{Textile Global Scenario}

Worldwide materials and garments exchange has expanded fundamentally since the post standard administration. Notwithstanding, Pakistan offer in worldwide materials and apparel exchange has stayed stagnant because of changes in the circulation chain and the making of an uneven playing field by the importing nations through particular exchange understandings and exceptional access given to distinctive contender nations. By all inclusive bits of knowledge report the charge of materials and pieces of clothing trade has extended from US \$709 billion in 2012 to US $\$ 766$ billion in 2013 exhibiting an addition of 8.03 percent as mention in Table 1. The passages of Pakistani material and clothing trade has also extended from US \$12.9 billion in 2012 to US $\$ 13.8$ billion in 2013 with the addition of around 6.97 percent. The primary ten exporters saw positive improvement. The most raised improvement was seen by India, with 23 percent and the slightest was recorded by the Republic of Korea, with 2 percent. The top exporters stay in the same positions, aside from Vietnam which surpassed the United States in 2013 as the sixth greatest exporter of materials and clothing world passages. The European Union is the greatest shipper of attire record for 38 percent of world imports in 2013 took after by the United States with 19 percent of world imports [6].

\section{Pakistan Textile Industry}

Pakistan has advantage of being $4^{\text {th }}$ largest cotton producer in the world. There is so much potential to increase 
Table 1. Export of textile and clothing.

\begin{tabular}{|c|c|c|c|c|c|c|c|}
\hline \multirow[b]{2}{*}{ Export of Textile and Clothing } & \multicolumn{7}{|c|}{ (USD \$Billion) } \\
\hline & 2007 & 2008 & 2009 & 2010 & 2011 & 2012 & 2013 \\
\hline World Textiles & 240.4 & 250.2 & 209.9 & 250.7 & 294 & 286 & 306 \\
\hline World Clothing & 345.8 & 361.9 & 315.1 & 351.5 & 412 & 423 & 460 \\
\hline Total & 586.2 & 612.1 & 525 & 602.2 & 706 & 709 & 766 \\
\hline Pakistan Textiles & 7.4 & 7.2 & 6.5 & 7.8 & 9.1 & 8.7 & 9.3 \\
\hline Pakistan Clothing & 3.9 & 3.9 & 3.4 & 3.9 & 4.6 & 4.2 & 4.5 \\
\hline Total & 11.3 & 11.1 & 9.9 & 11.7 & 13.7 & 12.9 & 13.8 \\
\hline Percentage of Total Trade & $1.93 \%$ & $1.81 \%$ & $1.89 \%$ & $1.94 \%$ & $1.94 \%$ & $1.82 \%$ & $1.80 \%$ \\
\hline
\end{tabular}

Source: World Trade Organization.

the crop yield. Furthermore Pakistan is the $3^{\text {rd }}$ largest yarn producer in the world. Textile process value chain is long like starting from cotton to finished garment. The material fragment in Pakistan has stayed stagnant over the span of the latest decade on account of different exogenous and indigenous variables [6]. On the private side, cotton creation has stayed stagnant at around 13 million packages for every annum and the impenetrability to assessing and organization of cotton groups by ginners and spinners alike has dependably cut down the estimation of Pakistani cotton by around 10 pennies for each pound in the overall business part. On the other hand, the value included pieces of attire part has turned out to be scarcely in view of its limited thing reach, low utilization of fake strands and disappointment of collecting units to reconstruct to meet changing worldwide necessities. Government has pronounced material game plan 2014-19. The group passes on unprecedented commitment drawback rates, commitment special case on plants and equipment, sponsorship on whole deal credits and change apportionments. The policy offered about Rs. 64.15 billion cash apportionment to the material and clothing range to help charges to \$26 billion by 2019 from $\$ 13$ billion (Money related Survey of Pakistan 2014-2015). The finance division will give Rs. 40.6 billion over the five years for commitment drawback, and development up-degree, while another Rs. 23.5 billion will be obliged capacity change, gave material presentations, establishment of world material center, weaving city, incubation facilities, garments house, and super material rewards [6].

\section{Research Methodology}

Utilizing computerized advertising without a vital methodology is still ordinary. It is certain a significant number of the organizations in this class are utilizing advanced media viably and they could surely be getting awesome results from their pursuit, email or online networking marketing. Yet, it is just as beyond any doubt that numerous are missing open doors or are experiencing alternate difficulties. In this rising situation, across the board use of innovation is required not just to update the nature of items, focus purchaser decisions, additionally to overcome professional impediments and diminish overhead expenses on unsold inventories. The developed countries are as of now concentrating on niche items like defensive dress, apparel for medicinal use by creating aggressiveness in novel "nanotechnology" coatings, more noteworthy appropriation of Product Life-cycle Management (PLM) Systems, keeping in mind the end goal to convey new "quick design" ideal models, while in the meantime remaining relentlessly dedicated to lower generation costs. It is regular practice for retailers to bargain with manufacturers, with brought together purchasing what's more, significant arrangement on costs, quality and conveyance plans [25]. The expansion of the middle person has happen as a consequence of expanding globalization inside of the business. The material and garments store network is right now turning out to be more worldwide, with numerous organizations either sourcing segments from abroad, or moving assembling to nations with lower work costs. Various procedures have been utilized in the textiles and apparel production network in request to enhance management, these incorporate speedy reaction and precise response [26]. It is getting to be evident that it is essential that going into associations are of foremost significance when creating business-to-business e-trade operations [27]. Then again, in spite of the fact that this may sound straightforward, in all actuality it is prone to be a great deal more perplexing.

\subsection{Conceptual Framework}

A question arises what should be the structure of textile industry in developing countries like Pakistan and then 
another issue is how these structure can be best fit in the e-marketing culture. Hu Ya-Ping [28] developed ageneral three stage e-marketing model which explains the operational, tactical and strategic levels which did not define the application in textile sector. Further this model also not showing the marketing mix which is very much important in decision making. We developed the following innovated two stage e-marketing model with adding marketing mix for effective decision making in Pakistani textile industry environment perspective. In e-marketing digital environment, this model provides the strategic direction to the managers for long term planning and decision making.

The results of e-marketing model are easier to evaluate as compare to traditional marketing model; and another benefit is that a digital system can achieve an unlimited audiences through internet. E-marketing is very interactive system to approach the intended audience. There are numerous ways to contact directly between the business and audience, in which business can get valuable customer feedback [11]. Following are benefits are listed of e-marketing model shown in Figure 2 considering its application in textile sector of Pakistan:

- It is very helpful to reach the desired audience in target market as per defined demographics and geographic factors.

- With implementation of the e-marketing model, due to real digital data business results can be measureable.

- It is a dynamic way to change the marketing efforts to promote business in local as well as in international markets.

- There is much more cheaper cost of customer acquisition.

- With consideration of marketing mix, it is very helpful for effective decision making.

- This model is accessible to all type and size of businesses.

- This model is helpful to strengthen the business relationships between the firm and customers.

- Keeping in view the marketing mix, lower customer cost acquisition this model is provide strategic direction to firms for effective decision making.

Following two stages model is emphasized the development of e-marketing culture and its application in tex-

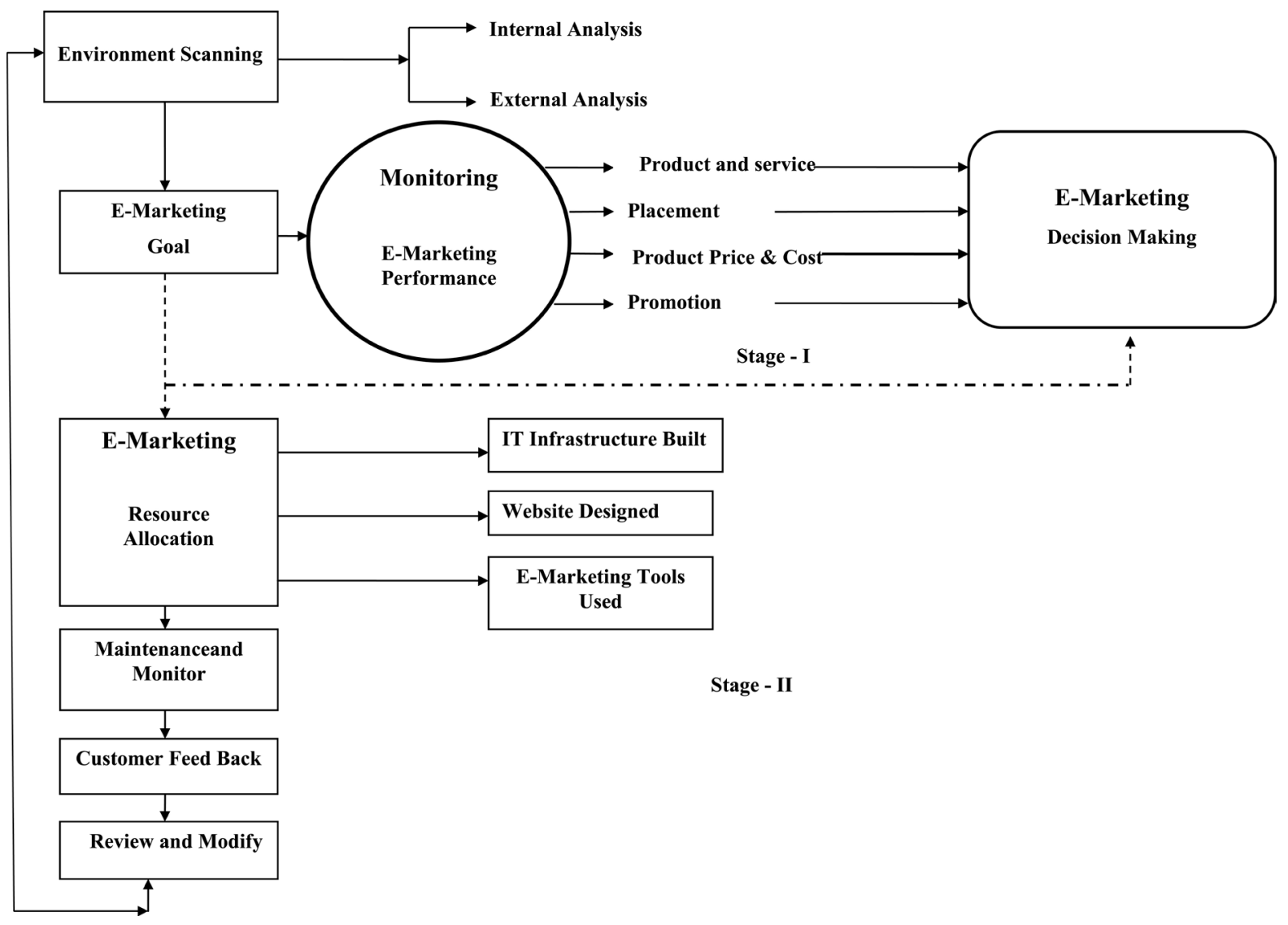

Figure 2. E-Marketing model developed by author. 
tile industry of Pakistan.

\subsubsection{Model 1: E-Marketing Development Model}

\section{1) E-marketing development model-stage-l}

Marketing planning is essentially a legitimate arrangement and an arrangement of actives prompting the setting of marketing objectives and formulation of plans for accomplishing. This definition recognizes between key marketing plans and strategic marketing arrangements. What's more, it is more helpful to add to an approach for e-marketing development.

There are three key issues stressed in creating procedure:

- Identifying the changing of aggressive environment.

- Defining the innovation in decision making considering e-marketing goals and e-marketing mix.

- Defining the e-marketing resources allocation and customer feedback for the betterment of the whole system The two stages are separated by dotted lines in first stage, the step by step analysis as under:

As business ends up being more forceful, and there are fast changes in the external environment, information from outside environment adds noteworthy segments to the ampleness of whole deal orchestrates. As environment is alterable, it gets the opportunity to be indispensable to recognize contenders' moves and exercises. Affiliations have moreover to upgrade the middle abilities and inside environment as indicated by external environment. Looking at the business environment needs an assessment of the engaged structure of the affiliation's business, including the forceful position of a particular affiliation and its principal enemies. Looking at the national environment needs an assessment of whether the national structure helps with accomplishing high ground in the globalized environment. Examination of full scale environment joins exploring extensive scale money related, social, government, honest to goodness, creative and overall parts that may affect the earth. The examination of relationship's outside surroundings reveals opportunities and risks for an affiliation. Inside environment of the company like company structures, policies, departmental work, strategies management style of working contribute a lot towards business success.

In today's furiously aggressive business environment, web promoting is a basic segment of a coordinated and viable marketing methodology. The new virtual business opportunities are made by e-trade. Around the world economy is progressively in view of data and impalpable quality. This development causes virtual types of business sector space. Virtual commercial center is the stage to unite supply and request and additionally innovation furthermore, financial prerequisites to improve the work of assets and organization and in addition the offering procedure [20]. Before you contribute on the web, you have to ensure you have the right mentality to move forward. Your business site ought not to be viewed as an IT cost, PC cost, or web cost. While it might be those, most importantly it is a promoting cost The internet has changed the way we offer our products and services. That is an actuality, buyers utilize the web to research and buy items on the web, so firms need online methodologies to pull in and hold clients. The e-marketing blend revives the marketing blend prepared for the online market place. Textile companies offering products through electronic mails to different buyers around the world. Mostly all export companies in Pakistan are using e-marketing tools to offer their products to international markets around the world. Many companies in Pakistan have maintained the e-marketing system to serve customers in a better way. Prices are also negotiated through the using of e-marketing tools; many customers around the world negotiate prices through electronic emails and video conferencing. Customers have better opportunity to compare the prices electronically received from different suppliers around the world. Here in Pakistan mostly export based companies negotiate the prices through electronic mails to respond to customers quickly and to conclude the contracts. Mostly all export based companies are deciding the distribution/placement of textile orders through e-marketing tools, and electronic emails in which companies commit formally about product quality and shipments to overseas customers.

Promotion is very much important while discussing the 4 Ps of marketing, companies pay too much attention to promote the products in the mind of customers. Pakistani textile companies normally use personal relations and to some extent e-marketing tools to promote their textile products both local and international markets. For a better decision making companies go through all the process as discussed above like internal and external analysis, considering marketing goals and 4 Ps of marketing. Right analysis provides the right direction in decision making. This all process support managers to go for a better decision for the best interest of the company.

\section{2) E-marketing development model-stage-II}

Companies put resources in e-marketing to achieve their goals. For resource allocations textile companies 
build IT infrastructure, design effective website and implement different e-marketing tools to attract the customers towards their products. Companies maintain the website with update information, product contents and solve the customer problems effectively. The website advertising uses the stage of website to do a progression of marketing exercises which incorporate brand advancement, occasion arranging, individual picture bundling, item promulgation, and so on. By and large, the website of apparel endeavor has the components of rich pictures, video materials and immense effect of showings. It can stir people in general consideration through consideration and sending; catch customer's eyes through item experience and road shooting subject; distribute some style data to expand consideration or utilize the well-known occasions for promoting. This is better time sharp our other e-marketing tools and techniques. While setting up an e-marketing effort, electronic apparatuses are utilized to accomplish your internet promoting targets. There are a plenty of instruments accessible to encourage e marketing, however organization does not need to utilize every one of them. An e-marketing arrangement can be a piece of a conventional promoting effort, or capacity as a standalone internet marketing effort. After successful implementation of e-marketing tools and techniques, its maintenance and monitoring is required when and how depend upon how you are using your system in fact how well your personal are using, is they are train for this? And is they know the tools very well? Client criticism is vital in light of the fact that it gives advertisers and entrepreneurs with knowledge that they can use to enhance their business, items and/or general client experience. Listening to your customers is the most ideal approach to guarantee you make a thing or organization that they truly need to buy. Customer information is usually used all through the thing headway method to ensure that the choosing thing is something that handles a customer's issue or fulfills a need. In business, a change organization technique depicts specific courses in which an affiliation will address such things as changes in the store system, stock necessities, arranging or wander extension. The target of building up a formal strategy is to ensure that any negative effects of advancement will be minimized. To satisfactorily discovered a change organization framework, accomplices must make a plan for how to see when a change is need, how to support changes, how to complete changes and how to screen changes to ensure they have understood the pined for effect. Administration ought to change and alter the entire framework as per e-marketing procedure.

\subsubsection{Model 2: E-Marketing in the Textile Sector of Pakistan}

As indicated in the Figure 3. In Pakistan textiles the e-marketing activities starts in the spinning sub sector in the textile value chain process and this sector mostly comprises of large mills. In Spinning lab companies test the cotton and yarn specifications through online and offline automated equipment. Spinning sub sector not only exports yarn but it is also supplied to the local market for further value addition. Most of the marketing and e-marketing actions are carried out by the knitting and weaving units and then convert these fabrics into finishing units where mostly the printing and dyeing are done as a value addition process, because after this process most of the fabric is exported directly or with little value addition in the form of bed ware which is one of the main items exported from this sector. There are only few companies which truly e-market their products. Most of the companies use internet for routine communication purpose. Pakistan textile sector mostly consists of small and medium enterprises so e-marketing is imperative to promote their products in international market and offer best competitive prices to customers to conclude the business. Some large manufacturing units like Nishat Textiles, Sapphire Textiles, Mahmood Group, Masood Textiles, Interloop Ltd. etc. They are all using the most updated machinery in their production processes and finalizing all the export orders through emails, online communication, and video conferencing and using different e-marketing tools to achieve the company objectives. Customers required detailed information about the products and services when buying on the internet and also viewed for prices comparison information and vendor information [29]. E-marketing applications are definitely helpful for the textile companies to achieve the company goals.

\section{E-Marketing Tools}

The following are the e-marketing tools which Pakistani organizations are using to promote their products.

\subsection{E-Market Places}

There is doubtlessly web has fused all the worldwide markets. Presently individuals can openly purchase and offer their products \& administrations through the web. E-services can be used to appropriate the items and administrations proficiently. As it were, it can change and motorize the clients, connections and commercial center 


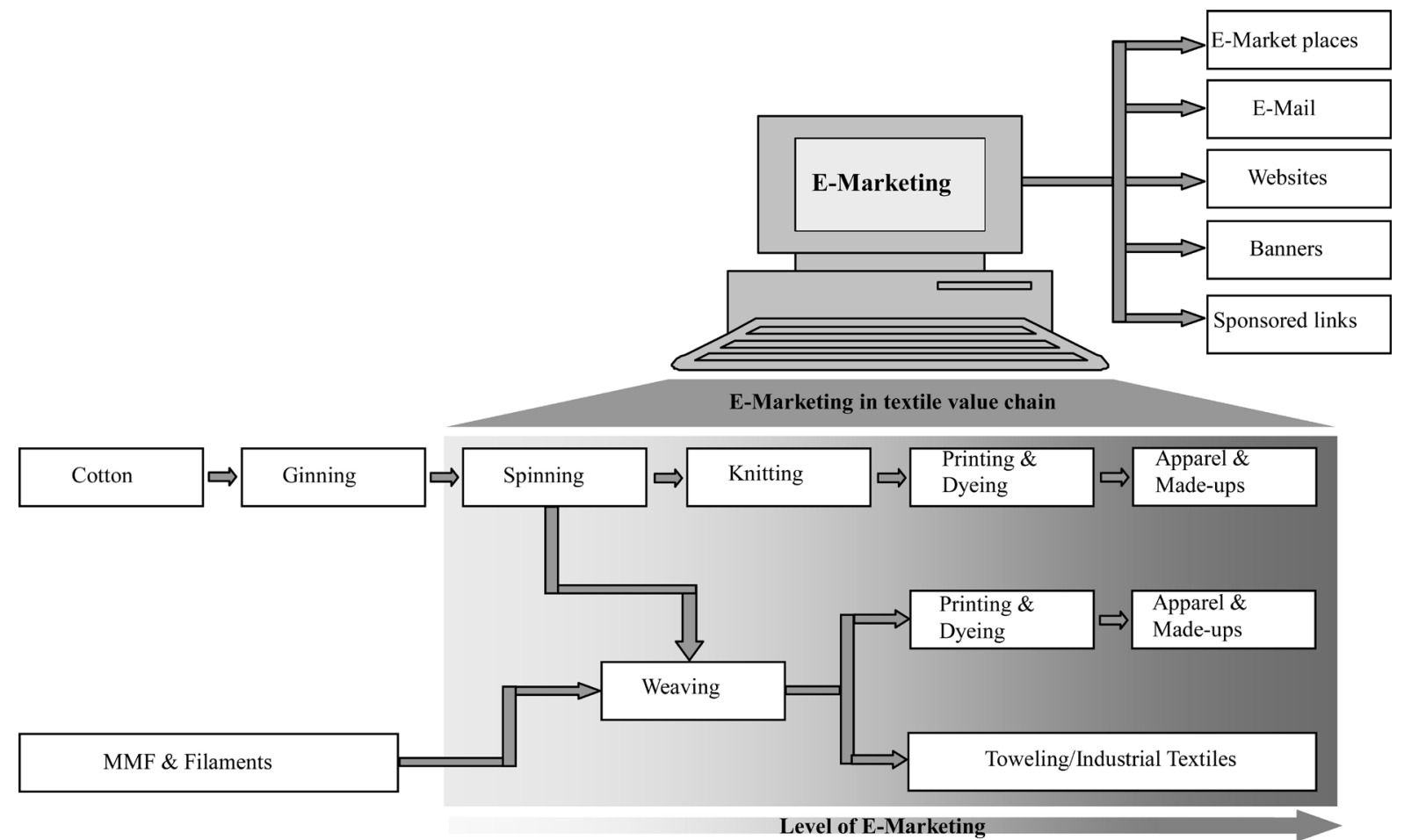

Figure 3. E-Marketing in the textile sector of Pakistan.

[30]. E-commerce is normally transactional in nature where transactions are conducted through internet but in textiles sector the sole objective of e-commerce is not just transaction but it more than that. It is a blend of e-marketing and e-business where the products\& services are promoted and sold as well Waghmare [31] pointed out that many Asian countries are taking advantage of e-commerce through opening of economies, which is important for encouraging more competition and distribution of internet technologies. Many services have been launched to electronic markets for the last ten years, and definitely the same kind of advancement continues. In many instances human work is partly switched to computers and soft wares due to additional services drive to electronic environment [32].

In Pakistan, there are many companies are working in e-market places. Pakistan TEX is leading e-market place where it provides unique e-marketing services for the small textiles units, clothing, linens, fabric, yarn and other textile products industry in Pakistan. They offer membership free of cost. This forum is very helpful for all the textile companies to promote their products and do good business for their growth.

\subsection{E-Mail}

One of the most successful types of internet based e-marketing is the use of electronic mails. Mostly all international buyers and sellers are using emails to promote their business around the world. Currently many large and small textile organizations of Pakistan attend all textile trade exhibitions held around the world where information is exchanged for future contracts and develop new relationships with the buyers and sellers. Mostly all companies use email campaign to develop new customers as well as retain existing customers. Through emails companies can send their brochures, product specifications, prices, shipments and many more information to their present and new customers. However one drawback is the spam email which might threaten the potential customers and often these mails are deleted straight way without reading. For this e-marketing tool the cost is very low and company can use this tool to utilize the best interest of the company.

\subsection{Websites}

A website is a set of electronic pages of information that are updated and available on internet for all information about the company history, business, products and services. The World Wide Web is interlinked, hypertext 
documents accessed through internet around the world mostly. On website there are visual effects that attract the customers to buy products. This is a good source for the smaller companies to promote their business in international markets and also threatens the big companies. Transactions can also be performed on websites, and payment can be made through credit cards and through other intermediaries. Websites are helpful and convenient source for exchanging information between buyer and sellers either in the home country or outside the country. This is cheaper source of communication and companies effectively using this tool for promoting their business.

In Pakistan textile sector many large and small organizations have attractive websites with huge information regarding their business history, growth, products and services information which are helpful the buyers to evaluate suppliers and develop good business relationships.

\subsection{Banners}

Banners are graphic advertisements which are displayed on a website and it is very helpful to build brand information or promote business for the advertiser's Web site. Currently banners are most popular form of advertisement on the internet (World Wide Web). Banners can be used to promote products, services and even the websites in local and international markets. This is a paid form of advertisement. Banner advertisements are posted on high traffic web pages/blogs/sites for a certain time period. Companies purchase time period for posting their ads in the form of banners. The banner advertisements can be displayed anywhere on the website as their rates differ according to location for posting of banners on the website. A banner is a hyperlink, when the user clicks on it; the user gets more information about the advertisement. The banner effectiveness can be measured by click through rating which is generated with result of number of hits. There are two type of banner advertisement, i.e. dynamic banners which are rotating and changes for each user and the static banner which does not change.

\subsection{Sponsored Links}

This is another form of e-marketing tool to promote the products and services on internet. This is similar to banners advertisement but with a difference that these advertisements can be seen mostly on search engines such as Yahoo, Google, Alta Vista etc. Many users hunt information through search engines so these search engines sell their search results. When a user put some keywords on the search engine, it displays sponsored links as well the information related to those particular keywords. In Google these sponsored links normally appear on the top or right side which showing various sponsored links and sometimes, if appropriate, the first two research results are for the sponsoring websites. This is very useful tool to promote the Pakistani textile products business in local and international markets where large number of customers can get information as per their requirements. The effectiveness of sponsored links has an advantage that the information related to specific keywords almost fulfills the requirement of the information seeker. Currently Pakistani textile companies are using this tool to promote their brands like Breeze etc.

\section{Practical Implication}

This paper guides the managers to apply the e-marketing tools in Pakistan textile sector with the objective to serve the customers in a better and unique way, and this application also provide the competitive advantage to the companies. E-marketing development model help the business managers comprehensively in all areas while implementing e-marketing to the textile business in Pakistan. Stage one helps the managers to scan the whole environment internal forces and external forces, then e-marketing goals helps to analyze the all 4 Ps i.e. product, pricing, placement and promotions for effective decision making. Stage two guides about all resources allocation like IT infrastructure, website design and e-marketing tools and then to maintain and monitor the whole process and finally customer feedback help to improve the business performance.

E-Marketing textile value chain model also defined the whole process of textiles like start from cotton production to finish fabrics. E-marketing tools are helpful to influence the local and international customers to develop the good relationships with the company. After studying the paper business managers can know the all textile value chain process and then implementation of e-marketing goals to achieve the corporate objectives of the company.

\section{Conclusions}

This paper demarcated about the textile value chain process and guide about application of e-marketing in the 
textile sector of Pakistan. E-Marketing model helps the companies to conduct thorough analysis, to review the e-marketing goals with considering marketing mix for effective decision making. Internal and external environment analyses are important to know affecting factors on decision making of the companies. Thorough analysis provides the strategic direction to the company for forecasting upcoming trends in business environment. Marketing goals also provide the strategic direction to the company, similarly marketing mix 4 Ps guides the companies what product and services are important to offer in the target market with the right price that is easily accessible to the customers. E-marketing model also helps the companies about resources allocation, monitor and maintenance and finally customer feedback to improve the business processes. Resources are very much important to achieve the company goals. Right decision making for resource allocations provide the competitive advantage to the company, similarly customer feedback is very much important to improve the production processes to acquire the new customers as well as retain the existing customers.

E-marketing is best model with economically lower cost reach customers in local and international markets for ultimately achieving the company objectives. The Pakistani textile value chain is very complex processes industry and the level of e-marketing is different in each sub sector of the textile sector in Pakistan. The textile sector is very important source of foreign exchange earnings in the economy of Pakistan. This sector mainly composed of small and medium enterprises and there are few large organizations. The potential of e-marketing is not being utilized in the textile sector of Pakistan. In this sector, mostly e-marketing activities are carried out through e-mail, websites, and e-market places. Our present work gives an outline idea and basic information regarding e-marketing application in Pakistan's textile industry. Further exploration and empirical research is required to know the business volume results through the application of e-marketing and to know return on investment in e-marketing with comparison to traditional marketing and its effectiveness to reach the customers in local and international markets and customer relationship development through e-marketing.

\section{References}

[1] Sheth, N.J. and Sharma, A. (2005) International E-Marketing: Opportunities and Issues. International Marketing Review, 22, 611-622. http://dx.doi.org/10.1108/02651330510630249

[2] Taherdoost, H., Sahibuddin, S. and Jalaliyoon, N. (2013) E-Services Usage Evaluation; Applications’ Level of CoCreation and Digitalization. International Journal of Academic Research in Management, 2, 10-18.

[3] Gangeshwer, D.K. (2013) E-Commerce or Internet Marketing: A Business Review from Indian Context. International Journal of $u$ - and e-Service, Science and Technology, 6, 187-194.

[4] Diola, Z.S. and Tichepco, E.M. (2008) Marketing for Filipinos.

[5] Sonnenberg, N., Jacobs, B. and Momberg, D. (2014) The Role of Information Exposure in Female University Students' Evaluation and Selection of Eco-Friendly Apparel in the South African Emerging Economy. Clothing and Textiles Research Journal, 32, 266-281. http://dx.doi.org/10.1177/0887302X14541542

[6] Economic Survey of Pakistan (2014-2015). http://www.finance.gov.pk/survey/chapters_15/Highlights.pdf

[7] Prashantham, S. (2003) The Internet and International Marketing. The Marketing Review, 3, 403-418. http://dx.doi.org/10.1362/146934703771910044

[8] Mayer, J. (2003) Trade Integration and Shifting Comparative Advantage in Labor-Intensive Manufactures. The UNU/ WIDER Conference on Sharing Global Prosperity, Helsinki, 6-7 September 2003.

[9] Meng, X.M. (2009) Developing Model of E-Commerce E-Marketing. Huangshan, 21-23 August 2009, $225-228$.

[10] Watson, R.P., Leyland, F.P., Berthon, P. and Zinkham, G. (2002) U-Commerce: Expanding the Universe of Marketing. Journal of the Academy of Marketing Science, 30, 333-347. http://dx.doi.org/10.1177/009207002236909

[11] Taherdoost, H. and Jalaliyoon, N. (2014) Marketing vs E-Marketing. International Journal of Academic Research in Management (IJARM), 3, 335-340.

[12] Eid, R. and El-Gohary, H. (2013) The Impact of E-Marketing Use on Small Business Enterprises' Marketing Success. The Service Industries Journal, 33, 31-50. http://dx.doi.org/10.1080/02642069.2011.594878

[13] Krishnamurthy, S. (2006) Introducing E-MARKPLAN: A Practical Methodology to Plan e-Marketing Activities. Business Horizons, 49, 51-60. http://dx.doi.org/10.1016/j.bushor.2005.05.008

[14] Cheema, A. and Kaikati, A. (2010) The Effect of Need for Uniqueness on Word of Mouth. Journal of Marketing Research, 47, 553-563. http://dx.doi.org/10.1509/jmkr.47.3.553

[15] Gershoff, A. and Johar, G. (2006) Do You Know Me? Consumer Calibration of Friends' Knowledge. Journal of Consumer Research, 32, 496-503. http://dx.doi.org/10.1086/500479 
[16] Anderson, J.C. and Narus, J.A. (1998) Business Marketing: Understand What Customer’s Value. Harvard Business Review, 76, 53-65.

[17] Dick, A. and Basu, K. (1994) Customer Loyalty: Toward an Integrated Conceptual Framework. Journal of the Academy of Marketing Science, 22, 99-113. http://dx.doi.org/10.1177/0092070394222001

[18] HFTrusov, M., Bucklin, R. and Pauwels, K. (2009) Effects of Word-of-Mouth versus Traditional Marketing: Findings from an Internet Social Networking Site. Journal of Marketing, 73, 90-102. http://dx.doi.org/10.1509/jmkg.73.5.90

[19] Aljukhadar, M. and Senecal, S. (2011) Segmenting the Online Consumer Market. Marketing Intelligence \& Planning, 29, 421-435. http://dx.doi.org/10.1108/02634501111138572

[20] Bönke, D. (1998) Electronic Commerce in Tourism, European Commission: Electronic Commerce and Networking in Europe. Proceedings of EURO-MED Net' 98, Nicosia, 4-7 March 1998, 5-12.

[21] Awamleh, N.A. (2011) E-Governance: An Endless ES to the Same End a Field Survey in the University Community in Bahrain. Asian Journal of Business Management, 3, 40-49.

[22] Kollmann, T. (1998) Marketing for Electronic Market Places-the Relevance of Two Critical Point of Success. Electricity Market, 8, 36-39. http://dx.doi.org/10.1080/10196789800000039

[23] Grieger, M. (2003) Electronic Marketplaces: A Literature Review and a Call for Supply Chain Management Research. European Journal of Operational Research, 144, 280-294. http://dx.doi.org/10.1016/S0377-2217(02)00394-6

[24] Wang, H. (1997) A Conceptual Model for Virtual Markets. Information and Management, 32, 147-161. http://dx.doi.org/10.1016/S0378-7206(97)00017-7

[25] Bruce, M. (1999) Dangerous Liaisons: An Application of Supply Chain Modeling for Studying Innovation within the UK Clothing Industry. Technology Analysis \& Strategic Management, 11, 113-125. http://dx.doi.org/10.1080/095373299107618

[26] Chandra, C. and Kumar, S. (2000) Supply Chain Management in Theory and Practice: A Passing Fad or a Fundamental Change? Industrial Management \& Data Systems, 100, 100-114. http://dx.doi.org/10.1108/02635570010286168

[27] Angeles, R. and Nath, R. (2000) An Empirical Study of EDI Trading Partner Selection Criteria in Customer-Supplier Relationships. Information \& Management, 37, 241-255. http://dx.doi.org/10.1016/S0378-7206(99)00054-3

[28] Hu Ya-Ping, (2012) E-Marketing Development in Virtual Market-Space: A Strategic Perspective. Asian Journal of Business Management, 4, 359-366.

[29] Choy, R. and Loker, S. (2004) Mass Customization of Wedding Gowns: Design Involvement on the Internet. Clothing and Textiles Research Journal, 22, 79-87. http://dx.doi.org/10.1177/0887302X0402200110

[30] Taherdoost, H., Sahibuddin, S. and Jalaliyoon, N. (2013) Classification of Web Based Service User Type. International Conference on Advanced Computer Applications and Technologies, Kuching, 23-24 December 2013, 495-499. http://dx.doi.org/10.1109/acsat.2013.103

[31] Waghmare, G.T. (2012) E-Commerce, a Business Review and Future Prospects in Indian Business. Internet Marketing in India, Indian Streams Research Journal, 2.

[32] Taherdoost, H., Sahibuddin, S., Ibrahim, S., Kalantari, A., Jalaliyoon, N. and Ameri, S. (2012) Examination of Electronic Service Definitions. International Conference on Advanced Computer Science Applications and Technologies (ACSAT), Kuala Lumpir, 26-28 November 2012, 73-77. http://dx.doi.org/10.1109/acsat.2012.51 


\section{Submit or recommend next manuscript to SCIRP and we will provide best service for you:}

Accepting pre-submission inquiries through Email, Facebook, Linkedin, Twitter, etc A wide selection of journals (inclusive of 9 subjects, more than 200 journals)

Providing a 24-hour high-quality service

User-friendly online submission system

Fair and swift peer-review system

Efficient typesetting and proofreading procedure

Display of the result of downloads and visits, as well as the number of cited articles

Maximum dissemination of your research work

Submit your manuscript at: http://papersubmission.scirp.org/ 